\title{
RNA interference for CFTR attenuates lung fluid absorption at birth in rats
}

\author{
Tianbo Li, Shyny Koshy and Hans G Folkesson*
}

\begin{abstract}
Address: Department of Integrative Medical Sciences, Northeastern Ohio Universities Colleges of Medicine and Pharmacy, Rootstown, OH 44272 0095, USA

Email: Tianbo Li - Tianbo.Li@yale.edu; Shyny Koshy - skoshy@neoucom.edu; Hans G Folkesson* - hgfolkes@neoucom.edu

* Corresponding author
\end{abstract}

Published: 24 July 2008

Respiratory Research 2008, 9:55 doi:10.1 186/1465-9921-9-55

This article is available from: http://respiratory-research.com/content/9/1/55

(C) $2008 \mathrm{Li}$ et al; licensee BioMed Central Ltd.

This is an Open Access article distributed under the terms of the Creative Commons Attribution License (http://creativecommons.org/licenses/by/2.0), which permits unrestricted use, distribution, and reproduction in any medium, provided the original work is properly cited.

\begin{abstract}
Background: Small interfering RNA (siRNA) against $\alpha \mathrm{ENaC}$ ( $\alpha$-subunit of the epithelial $\mathrm{Na}$ channel) and CFTR (cystic fibrosis transmembrane conductance regulator) was used to explore $\mathrm{ENaC}$ and $\mathrm{CTFR}$ function in newborn rat lungs.
\end{abstract}

Methods: Twenty-four hours after trans-thoracic intrapulmonary (ttip) injection of siRNAgenerating plasmid DNA (pSi-0, pSi-4, or pSi- $\mathrm{C}_{2}$ ), we measured CFTR and ENaC expression, extravascular lung water, and mortality.

Results: $\alpha \mathrm{ENaC}$ and CFTR mRNA and protein decreased by $\sim 80 \%$ and $\sim 85 \%$, respectively, following $\alpha \mathrm{ENaC}$ and CFTR silencing. Extravascular lung water and mortality increased after $\alpha E N a C$ and CFTR-silencing. In pSi- $C_{2}$-transfected isolated DLE cells there were attenuated CFTR mRNA and protein. In pSi-4-transfected DLE cells $\alpha E N a C$ mRNA and protein were both reduced. Interestingly, CFTR-silencing also reduced $\alpha \mathrm{ENaC}$ mRNA and protein. $\alpha \mathrm{ENaC}$ silencing, on the other hand, only slightly reduced CFTR mRNA and protein.

Conclusion: Thus, ENaC and CFTR are both involved in the fluid secretion to absorption conversion around at birth.

\section{Background}

Fetal lungs are filled with fluid that is produced and secreted by the pulmonary epithelium and linked to $\mathrm{Na}$ coupled $\mathrm{Cl}$ secretion in utero. This fluid must be rapidly removed at birth for adequate gas exchange across the alveolar epithelium-endothelium at birth to occur. Failure to clear fetal lung fluid has been linked to preterm birth, inherited genetic diseases, and inflammation and may increase the risk of hypoxic injury to vital organs in newborn infants; such injuries representing $~ 4 \%$ of infant fatalities in 2002 [1].
Lung fluid absorption and secretion have been intensively studied [2-7]. Apical amiloride-sensitive epithelial $\mathrm{Na}$ channels $(\mathrm{ENaC})[8,9]$ and basolateral Na,K-ATPases $[10,11]$ have been demonstrated as key proteins for vectorial Na transport and lung fluid absorption. Recent studies in fetal rats found an accelerated lung fluid absorption between birth and $40 \mathrm{~h}$ postnatal age [12]. Lung $\mathrm{Cl}$ transport is traditionally associated with fluid secretion during lung development [2]. Studies of cultured alveolar type II epithelial cells suggest that cystic fibrosis transmembrane conductance regulator-(CFTR)-mediated $\mathrm{Cl}$ transport may 
also be involved $[13,14]$. There are, however, still some questions to CFTR involvement since these studies rely on cultured cells of uncertain phenotype and did not address the possibility that fluid transport may involve multiple different epithelial cell types, including alveolar epithelial type I cells $[15,16]$ and distal airway epithelial cells $[17,18]$. In fact, the Na transport machinery involved in lung fluid absorption as well as CFTR are present in both alveolar epithelial type I and II cells [19].

$\mathrm{ENaC}$ and CFTR functions have been assessed in $\alpha \mathrm{ENaC}^{-1}$ - $[8,20]$ and CFTR $^{-}-[21]$ mice, but these results may be confounded by various in vivo compensatory mechanisms. In the present study, our first aim was to adapt and use our recently developed RNA interference (RNAi) technique [9] to silence CFTR in newborn rats by trans-thoracic intrapulmonary (ttip) injection and to explore functional in vivo responses to the CFTR-silencing. Thus, we determined extravascular lung water and newborn mortality after CFTR-silencing. Our second aim was to use RNAi technology to silence CFTR in primary distal lung epithelial cells (DLE cells) and to compare the effects with the in vivo situation. Our third aim was to determine if CFTR-silencing affected lung $\alpha \mathrm{ENaC}$ expression and if $\alpha \mathrm{ENaC}$ silencing affected lung CFTR expression in vivo and in vitro.

\section{Materials and methods Animals}

Timed-pregnant Sprague-Dawley rats (wt 200-250 g, N = 28; Charles River, Wilmington, MA) were used in the study. The rats were housed separately in their cages in a temperature- and humidity-controlled environment ( $20 \pm$ $2{ }^{\circ} \mathrm{C}$ and $55 \pm 10 \%$ relative humidity). The rats were kept at a 12:12 h day-night rhythm and had free access to standard rat chow (Purina, Copley Feed, Copley, $\mathrm{OH}$ ) and tap water. All studies were reviewed and approved by the Institutional Animal Care and Use Committee (IACUC) at the Northeastern Ohio Universities Colleges of Medicine and Pharmacy, Rootstown, $\mathrm{OH}$.

\section{Plasmid construction}

siRNA-generating plasmids were constructed using a commercial plasmid (pSilencer 3.0-H1; Ambion, Austin, TX) with standard techniques [22]. Selected recombinants were sequenced (CEQ 2000XL; Beckman, Palo Alto, CA) to verify correct oligonucleotide frames and sequences. Plasmid DNA (pDNA) was amplified in Escherichia coli DH5 $\alpha$ and purified using the Wizard ${ }^{\circledR}$ PureFection pDNA Purification System (Promega Co., Madison, WI). This pDNA isolation kit has a specific resin-binding procedure to remove endotoxin from the pDNA. After isolation and purification, pDNA concentration and purity (ratio 1.71.8) was measured at $260 / 280 \mathrm{~nm}$ and samples were stored at $-80^{\circ} \mathrm{C}$.

\section{CFTR}

Rat CFTR mRNA [GenBank:XM 347229] secondary folding structure was predicted based on the principle of minimizing free energy, using RNA structure v. 3.71 software [9]. Two 19-nucleotide regions from cDNA, 3872-3892 bp and 3458-3478 bp, were selected and designed as targets for rat CFTR specific siRNA-generating pDNA, named pSi- $\mathrm{C}_{1}$ and $\mathrm{pSi}-\mathrm{C}_{2}$, respectively. Each target sequence was specific and did not match other sequences in the GenBank. For construction of siRNA-generating pDNA, two complementary oligonucleotides (forward and reverse), containing a sense strand, followed by a short spacer ( 5 'TTCAAGAGA-3'), an antisense strand, and a RNA polymerase III termination signal (5'-TTTTTTGGAAA-3'), were synthesized, annealed, and ligated into pSilencer 3.0-H1. Synthesized oligonucleotides with BamHI and HindIII overhangs were pSi- $\mathrm{C}_{1}$, forward 5'GATCCGTGGAGAGATGAAGAAATATTTCAAGAGAATATTTCTTCATCTCTCCATTTTTTGGAAA-3' psi-C ${ }_{1}$, reverse 5 'GCTTTTCCAAAAAATGGAGAGATGAAGAAATATTCTCTTGAAATATTTCTTCATCTCTCCACG-3'; pSi-C $_{2}$, forward 5 'ATCCGAAAGTATATGTACCAAGATTCAAGAGATCTTGGTACATATACTTTCTTTTTTGGAAA-3', pSi-C $_{2}$, reverse 5'AGCTTTTCCAAAAAAGAAAGTATATGTACCAA-

GATCTCTTGAATCTTGGTACATATACTTTCG-3'. As negative control we used a non-silencing sequence, 5'GATCCGTTACACTTTTTTGGAAA-3' (scramble, which does not correspond to any known transcript) with Bam $\mathrm{H} 1$ and HindIII overhangs, also inserted in pSilencer 3.0-H1, named pSi-0.

\section{$\alpha \mathrm{ENaC}$}

Rat $\alpha E N a C$ mRNA [GenBank:NM 031548] secondary folding structure was also predicted based on the principle of minimizing free energy as above. In our earlier study [9], we generated four pDNA constructs named pSi-1 pSi-4 for $\alpha \mathrm{ENaC}$ silencing. Pilot studies [9] demonstrated that pSi-4 was the most effective pDNA construct and was selected for these studies. The pSi-4 sequence corresponds to rat $\alpha \mathrm{ENaC}$ cDNA nucleotide positions $1617-1635$, is specific for rat $\alpha \mathrm{ENaC}$ and do not match other GenBank sequences. For construction of siRNA-generating pDNA, the same procedure as above was followed. The two oligonucleotides were: pSi-4, forward: 5'GATCCGTTACACTATTAACAACAAATTCAAGAGATTTGTTGTTAATAGTGTAATTT TTTGGAAA-3', pSi-4, reverse: 5-AGCTTTTCCAAAAAATTACACTAT-

TAACAACAAATCTCTTGAATTTGTTGTTAATAG

TGTAACG-3'. We also used the same negative control, pSi-0. 


\section{Solutions}

After measuring DNA concentration, the pDNA solution was either concentrated by a vacuum centrifuge (SVC100H; Savant Instrument Inc., Farmingdale, NY) or diluted with sterile deionized water to the required concentration. pDNA solution osmolality was measured by a Vapor Pressure Osmometer 5500 (Wescor Inc., Logan, UT), and if needed adjusted with sterile $\mathrm{NaCl}$ or deionized water to $100 \mathrm{mOsm}$. The pDNA solution was freshly prepared by mixing pDNA containing either $\mathrm{pSi}^{-} \mathrm{C}_{1}, \mathrm{pSi}^{-\mathrm{C}_{2}}$, pSi-4, or pSi-0 with Lipofectamine $2000^{\mathrm{TM}}$ (Invitrogen, Carlsbad, CA), under optimized transfection conditions [9]: pDNA $(\mu \mathrm{g})$ : Lipofectamine $2000^{\mathrm{TM}}(\mu \mathrm{l})$ ratio $1: 1$, generating a pDNA solution with the concentration $4 \mu \mathrm{g} / \mathrm{g}$ body wt in a final volume of $40 \mu \mathrm{l} / \mathrm{g}$ body wt for each newborn rat.

\section{pDNA delivery}

Timed-pregnant rats were observed for signs of labor and delivery. Newborn rats were removed from the dams within $1 \mathrm{~h}$ after birth. Freshly prepared pDNA/Lipofectamine solution was delivered trans-thoracically via the left pleural cavity to the lungs using a 30-G needle in a volume of $40 \mu \mathrm{l} / \mathrm{g}$ body wt [23]. Newborn rats were placed on a $37^{\circ} \mathrm{C}$ temperature-controlled pad after pDNA injection. The newborn rats were then allowed to recover in cages with their respective dams where they remained for the 24-h study.

\section{Specific protocols}

All newborn rats were pretreated with scramble pDNA (pSi-0), specific $\alpha$ ENaC-silencing pDNA (pSi-4), or specific CFTR-silencing pDNA solution $\left(\mathrm{pSi}^{-} \mathrm{C}_{1}\right.$ or $\mathrm{pSi}^{-\mathrm{C}_{2}}$ ) for $24 \mathrm{~h}$ as described above and divided into the following groups. Mortality was recorded in all experimental groups. Untreated: Newborn rat lungs were excised for either extravascular lung water or RT-PCR and western blot studies $(N=18)$. Pilot studies: For CFTR we tested the two candidate sequences in newborn rats, $\mathrm{pSi}^{-\mathrm{C}_{1}}(\mathrm{~N}=4)$ and $\mathrm{pSi}^{-\mathrm{C}_{2}}(\mathrm{~N}=4)$, and based on the efficiency data from our pilot studies, we selected $\mathrm{pSi}-\mathrm{C}_{2}$ as siRNA-generating pDNA for CFTR. Control: Newborn rats were ttip injected with irrelevant pDNA ( $\mathrm{pSi}-0, N=32$ ). Lungs were excised for either extravascular lung water or RT-PCR and western blot studies. CFTR siRNA: Newborn rats were ttip injected with CFTR siRNA-generating pDNA (pSi-C $\left.{ }_{2}, N=63\right)$. Lungs were excised for either extravascular lung water or RT-PCR and western blot studies. $\alpha E N a C$ siRNA: Newborn rats were ttip injected with $\alpha E N a C$ siRNA-generating pDNA (pSi-4, $N=40)$. Lungs were excised for either extravascular lung water or RT-PCR and western blot studies.

\section{DLE cell isolation, culture, and RNAi localization}

DLE cells were isolated from GD21 (GD = gestation day; term $=22$ days; $N=75$ fetuses from 6 dams) rat fetuses [24]. Briefly, dams were anesthetized with heparinized $(1,000 \mathrm{U})$ pentobarbital sodium $(50 \mathrm{mg} / \mathrm{kg}$ body $\mathrm{wt})$ intraperitoneally and placed in temperature-controlled environments. Rat fetuses were delivered one-by-one via abdominal hysterotomy. Between deliveries the uterus was kept closed by a non-injurious hemostat. Fetal lungs and hearts were excised en bloc (heart was removed and discarded) immediately after fetal decapitation. Lungs from each litter were pooled, rinsed twice in ice-cold HBSS (w/o $\mathrm{Mg} \& \mathrm{Ca}$ ), and minced to $<1 \mathrm{~mm}^{3}$. Fetal lung tissue was digested in HBSS containing $0.125 \%$ trypsin (Mediatech, Herndon, VA) and $25 \mu \mathrm{g} / \mathrm{ml}$ DNase I (MP Biochemicals, Aurora, OH) $20 \mathrm{~min}$ at $37^{\circ} \mathrm{C}$. After $20 \mathrm{~min}$, collagenase (USB Co., Cleveland, $\mathrm{OH}$ ) and additional DNase I were added to final concentrations of $0.1 \%$ and $50 \mu \mathrm{g} / \mathrm{ml}$, respectively, and digestion was continued for $20 \mathrm{~min}$. Enzymes were neutralized by adding $2 \mathrm{ml}$ FBS (fetal bovine serum; Atlanta Biologicals, Lawrenceville, GA) at $4^{\circ} \mathrm{C}$. Cell suspensions were transferred to new tubes by tituration to break up cell clumps. Dispersed cell solutions were filtered through $100 \mu \mathrm{m}$ cell strainers (Becton Dickinson Labware, Franklin Lakes, NJ), and then through $70 \mu \mathrm{m}$ cell strainers. DLE cells were collected by centrifugation (420 g; $6 \mathrm{~min}$ ) and resuspended in $15 \mathrm{ml}$ DMEM/F-12 (Dulbecco's modified Eagle medium/F-12 50/50; Cellgro, Herndon, VA). The DLE cells were purified by differential adherence steps. Cells were plated $2 \times 30$ min to remove fibroblasts. Cell yield was determined by a Beckman Coulter Z1 Coulter particle counter. The purity of the isolated DLE cells was on average 85-90\% DLE cells. Isolated DLE cells were seeded on 6-well plates (Corning, Acton, MA) at $10^{5}$ cells $/ \mathrm{cm}^{2}$ densities. All cells were submersion cultured in DMEM/F-12 with 10\% FBS in an atmosphere of $5 \% \mathrm{CO}_{2}, 21 \% \mathrm{O}_{2}, 74 \% \mathrm{~N}_{2}$ with $95 \%$ humidity.

DLE cells were also isolated from newborn rats ttip injected with pSi-0 or pSi-C 2 (each $N=6$ ) for $24 \mathrm{~h}$. These DLE cells were isolated following the same technique [24] with some modifications. Lungs and hearts were excised en bloc (heart was removed and discarded) immediately after fetal decapitation. Blood was collected. Lungs from each litter were pooled, rinsed twice in ice-cold HBSS (w/ o $\mathrm{Mg} \& \mathrm{Ca}$ ), and minced to $\sim 1 \mathrm{~mm}^{3}$. Lung tissue was then processed as described above. For RNAi localization, cells were collected by centrifugation $5 \mathrm{~min}$ at $1000 \mathrm{~g}$ and snapfrozen in liquid nitrogen for down-stream analyses.

\section{DLE cell transfection}

Isolated DLE cells were transfected at 60\%-80\% confluency ( 1 day after plating) in 6 -well plates using the prepared pDNA/Lipofectamine solution according to the 
manufacturer. Each transfection solution contained $10 \mu \mathrm{g}$ of pDNA, pSi- $\mathrm{C}_{2}, \mathrm{pSi}-4$, or pSi-0, and $10 \mu$ l Lipofectamine $2000^{\mathrm{TM}}$ in a total volume of $2 \mathrm{ml}$. After $6 \mathrm{~h}$ incubation, the transfection solution was replaced with $10 \%$ FBS containing DMEM/F-12 medium. Twenty-four hours later, the cells were lysed by appropriate lysis buffer depending on down-stream analyses.

\section{PCR}

A polymerase chain reaction (PCR) was used to detect pDNA after in vivo and in vitro pSi-0 transfection. Template DNA was isolated from lung tissue, DLE cells, and for control also kidney tissue using a DNA isolation kit (Promega Co., Madison, WI). A primer pair was synthesized targeting a pSi-0- specific sequence, pSi-0+: 5'CACTCGGATCCGTTACACTT-3', and pSi-0-: 5'-TAGTCCTGTCGGGTTTCG-3'. PCR was done with a PCR Master Mix kit (Promega). Reaction volume was $25 \mu \mathrm{l}$, with $50 \mathrm{ng}$ of template DNA and $0.1 \mu \mathrm{M}$ of each primer added, under optimized conditions: $95^{\circ} \mathrm{C} 30 \mathrm{sec}, 55^{\circ} \mathrm{C}$ for $30 \mathrm{sec}, 72^{\circ} \mathrm{C}$ for $1.5 \mathrm{~min}$, for 30 cycles, and final extension for $5 \mathrm{~min}$ at $72^{\circ} \mathrm{C}$. PCR amplification would yield a 127 -bp pSi-0-specific fragment. PCR products were resolved in 1.5\% agarose gel containing $1 \mu \mathrm{g} / \mathrm{ml}$ ethidium bromide. Gels were scanned by a Typhoon 8610 scanner (Molecular Dynamics).

\section{RT-PCR}

Total RNA was extracted from lung tissue, isolated DLE cells, and kidney tissue using a Versagene RNA isolation kit from Gentra (Minneapolis, MN). RNA yield and purity was determined spectrophotometrically at 260/280 nm and RNA integrity was verified by agarose gel electrophoresis. A competitive reverse transcriptase polymerase chain reaction (RT-PCR) was carried out using the OneStep RT-PCR kit (EMD, San Diego, CA). Total reaction volume was $25 \mu \mathrm{l}$, containing $50 \mathrm{ng}$ total RNA, $1 \times$ PCR buffer, $0.2 \mathrm{mM}$ of each dNTP, $2.5 \mathrm{mM} \mathrm{MgSO}_{4}, 0.1 \mu \mathrm{M}$ of each primer and $1.5 \mathrm{U}$ rTth DNA polymerase. The RT-PCR was optimized: $60^{\circ} \mathrm{C} 30 \mathrm{~min}$ reverse transcription, followed by 40 cycles at $94^{\circ} \mathrm{C} 45 \mathrm{sec}, 60^{\circ} \mathrm{C} 2 \mathrm{~min}$, and final extension $7 \mathrm{~min}$ at $60^{\circ} \mathrm{C}$. We tested in preliminary experiments 30 and 40 amplification cycles for pSi-4 [9]. We elected to use 40 cycles after analysis of outcome versus number of cycles and because we found that this amplification generated repeatable results. Three primer pairs $(+$, sense; -, antisense) were derived from GenBank sequences, and synthesized for competitive RT-PCR: aENaC [GenBank:NM_031548], ENa+: 5'-CATGATGTACTGGCAGTTCGC-3' (731-751), ENa-: 5'-TCCCTTGGGCTTAGGGTAGAAG-3' (1751-1772); CFTR [GenBank:XM 347229]， CF+: 5'-ACTTACTTTGAAACCCTATTCC-3' (3157-3178), CF-: 5'-AAGGCTTGTCTTAGAACTCG-3' (4102-4121); GAPDH [GenBank:NM 017008], GAPD+: 5'-ACCACAGTCCAT-
GCCATCAC-3' (1369-1388), GAPD-: 5'-TCCACCACCCTGTTGCTGTA-3' (1801-1820). Amplification of this competitive RT-PCR yields a 1042-bp $\alpha E N a C$ fragment, a 965-bp CFTR fragment, and a 452-bp GAPDH fragment (internal control). RT-PCR products were resolved in $1.5 \%$ agarose gels stained with $1 \mu \mathrm{g} / \mathrm{ml}$ ethidium bromide. Gels were scanned by a Typhoon 8610 Scanner. Densitometric analysis was carried out with TotalLab software (Nonlinear Dynamics Ltd, Newcastle upon Tyne, U.K).

\section{Western blot}

Lung tissue or isolated DLE cells from newborn rats in each experimental group was homogenized in T-Per ${ }^{\mathrm{TM}}$ Reagent (Pierce, Rockford, IL) containing protease inhibitors, aprotinin ( $30 \mu \mathrm{g} / \mathrm{ml}$; Sigma, St. Louis, MO) and leupeptin ( $1 \mu \mathrm{g} / \mathrm{ml}$; Sigma), with a homogenizer (Tissue Tearor) on ice. DLE cells were harvested in T-Per ${ }^{\mathrm{TM}}$ reagent and lysed by sonication. The homogenate was centrifuged at 13,000 $g$ for $5 \mathrm{~min}$ at $+4^{\circ} \mathrm{C}$. Supernatant (membrane and cytosol) was collected, aliquoted in multiple vials, and snap-frozen in liquid nitrogen. One vial was used for determining total protein concentration of the sample to ensure equal loading of the electrophoresis gel. Aliquots were stored at $-80^{\circ} \mathrm{C}$ until analyzed.

Polyacrylamide gel electrophoresis and transfer to nitrocellulose membranes (Pierce) were carried out using standard protocols. After the polyacrylamide gel electrophoresis and transfer, the nitrocellulose membranes were blocked (SuperBlock ${ }^{\mathrm{TM}}$ Dry Blend blocking buffer in tris buffered saline (TBS); Pierce) for $1 \mathrm{~h}$ at room temperature. After blocking, membranes were incubated with primary antibodies on an orbital shaker over night at $+4^{\circ} \mathrm{C}$. Primary $\alpha \mathrm{ENaC}$ antibodies were purchased from Alpha Diagnostics International (San Antonio, TX; used at 1:1,000 dilution) and directed against $\mathrm{N}$-termini of $\alpha \mathrm{ENaC}$. The antibodies recognize membrane proteins of appropriate sizes (85-95 kDa) in rats. Primary CFTR antibodies were bought from Santa Cruz Biotech, Inc. (Santa Cruz, CA; used at 1:1,000 dilution) and directed against amino acids 1-182 mapping the CFTR N-terminus. The antibody recognizes a membrane protein of appropriate size $(\sim 150$ $\mathrm{kDa})$ in rats. Monoclonal anti-GAPDH antibodies (GAPDH used as loading and transfer control; 1:1,000 dilution) were purchased from Cell Signaling Technology, Inc. (Danvers, MA), detects GAPDH of rat origin, and cross-reacts with guinea pig GAPDH (37 kDa). After incubation, membranes were washed $5 \times 10 \mathrm{~min}$ with wash buffer ( $\mathrm{pH}=7.5$; TBS with $0.1 \%$ Tween-20). Membranes were incubated with HRP-conjugated secondary antibodies (goat-anti-rabbit IgG; used at 1:1,000 dilution) for $1 \mathrm{~h}$ at room temperature. After incubation, membranes were washed again. Substrate solution (SuperSignal ${ }^{\circledR}$ West Femto; Pierce) was added and incubated for $5 \mathrm{~min}$. The 
luminescence signal was detected using a Kodak image analyzer and densitometrically analyzed using TotalLab software.

\section{Extravascular lung water}

To measure extravascular lung water in newborn rat lungs, we modified the original method described previously [25]. Extravascular lung water was measured in untreated $(N=20)$, pSi-0-injected $(N=10)$, pSi-4-injected $(N=12)$, and $\mathrm{pSi}-\mathrm{C}_{2}$-injected $(\mathrm{N}=15)$ newborn rats from 3-4 litters each. The lungs were rapidly excised, hearts removed, and placed in pre-weighed sample tubes and re-weighed. Water $(250 \mu \mathrm{l})$ was added, lungs were weighed again, and homogenized using a Tissue Tearor. If the extravascular lung water determinations were not done the day of lung harvest, collected lungs were weighed, water $(250 \mu \mathrm{l})$ added, and lungs were re-weighed and stored frozen at $20^{\circ} \mathrm{C}$ until analysis. Parts of lung homogenates were centrifuged $5 \mathrm{~min}$ at $14,000 \mathrm{~g}$. Blood was collected from a small number of newborn rats after decapitation to obtain a hemoglobin $(\mathrm{Hb})$ value for newborn rat blood. Hb content was measured on supernatants obtained after centrifugation and blood volume of newborn rat lungs were calculated from homogenate supernatant $\mathrm{Hb}$ concentration relative to blood $\mathrm{Hb}$ concentration. Newborn rat blood wet-dry weight was determined. Lung wet-to-dry weights were corrected for blood volume. Drying of lung homogenates, lung homogenate supernatants, and newborn rat blood was carried out using a moisture analyzer (Sartorius, Edgewood, NY) that continuously recorded water loss as samples dried. Each sample was dried at 80$120^{\circ} \mathrm{C}$ until dry weights reached stability. Typically, this procedure required $15 \mathrm{~min} / \mathrm{sample}$. Non-specific water loss of wet samples and non-specific re-humidification of dried samples, as may occur when small samples are measured by traditional extravascular lung water techniques, was prevented in this analysis. We verified the technique by comparing it to traditional techniques [25] in adult rat lungs.

\section{Statistics}

All data are presented as means \pm SD. Data were analyzed with one-way analysis of variance (ANOVA) with Tukey's test as post hoc or Student's $t$ test as appropriate. Differences were considered significant when $P<0.05$.

\section{Results}

\section{Lung CFTR mRNA during development}

We determined if CFTR transcription changed during early postnatal development. Lung total RNA from newborn, 2-day-old (D), and adult rats were isolated. CFTR mRNA was determined by RT-PCR. GAPDH was used as internal control. CFTR transcription was $\sim 2 \times$ higher in newborn than in adult rats (Fig. 1). CFTR transcription

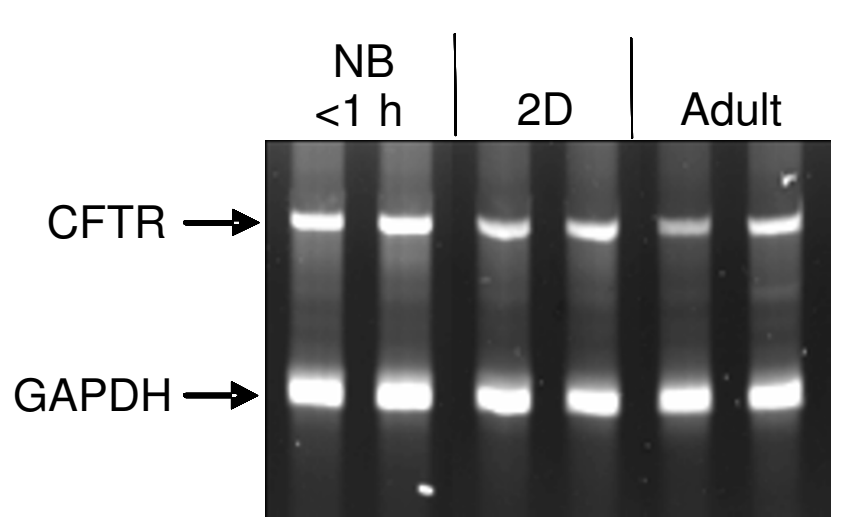

Figure I

CFTR mRNA during early postnatal life of the rat to adulthood. CFTR mRNA was measured by RT-PCR in lung tissue from newborn (NB), 2-day-old (2D), and adult rats. Representative RT-PCR gels are shown for lung CFTR and GAPDH (internal standard) mRNA.

levels decreased during the first postnatal days and reached adult levels on postnatal day 2 .

We then investigated if the selected siRNA-generating pDNA silenced CFTR both in vivo after ttip injection and in vitro in isolated DLE cells to assure its functionality for the further studies. We found that $\mathrm{pSi}^{-} \mathrm{C}_{2}$ was equally effective under either optimized condition to silence CFTR expression in both whole lung and DLE cells (Fig. $2 \mathrm{AB})$.

RNAi for CFTR in newborn rat lungs and isolated DLE cells We also carried out a comprehensive study to determine if pSi- $\mathrm{C}_{2}$ silenced CFTR in newborn rats. After ttip pSi- $\mathrm{C}_{2}{ }^{-}$ injection, as shown in Fig. 3A, CFTR mRNA was decreased by $\sim 80 \%$. Western blot results demonstrated that $\mathrm{pSi}-\mathrm{C}_{2}$ also decreased CFTR protein by $\sim 80 \%$ (Fig. 3B). We then investigated if CFTR-silencing affected $\alpha \mathrm{ENaC}$ expression. As shown in Fig. 3A and Fig. 3B, CFTR-silencing also reduced $\alpha \mathrm{ENaC} \mathrm{mRNA}$ and protein.

We turned our attention to confirming this in isolated DLE cells from rat fetuses. We therefore studied RNAi silencing of CFTR in these isolated DLE cells after pSi- $\mathrm{C}_{2}$ pretreatment. DLE cells (isolated at GD21) were transfected with the pDNA 1 day after cell plating. Twenty-four hours after pDNA transfection, i.e., GD22 (birth), CFTR and $\alpha \mathrm{ENaC}$ mRNA and protein were detected by RT-PCR and western blot, respectively. As shown in Fig. 3C, pSi$\mathrm{C}_{2}$-transfection decreased CFTR mRNA by $\sim 80 \%$, compared to pSi-0 transfected matched DLE cells. As seen in Fig. 3D, western blot results emonstrate that, $\mathrm{pSi}^{-\mathrm{C}_{2}}$-transfection also decreased CFTR protein by 90\%. 
A

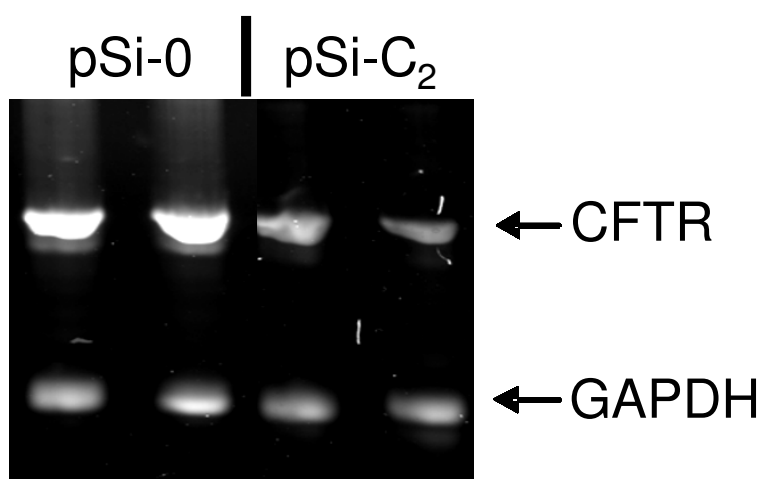

ttip injection
B

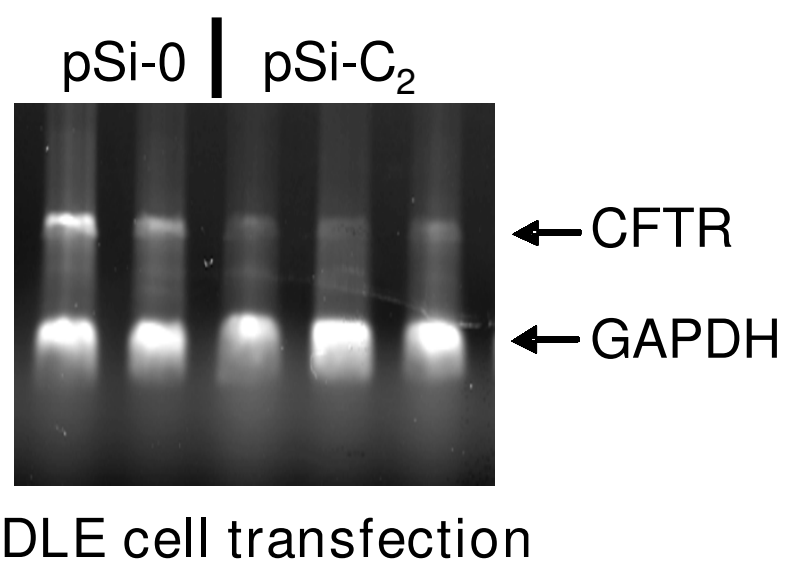

Figure 2

CFTR mRNA in newborn rat lungs $24 \mathrm{~h}$ after ttip pSi- $\mathrm{C}_{2}$-injection (A) and CFTR mRNA in isolated DLE cells $24 \mathrm{~h}$ after $\mathbf{p S i}-\mathbf{C}_{\mathbf{2}}$-transfection (B). Representative RT-PCR gels are shown for lung CFTR and GAPDH (internal standard) mRNA.

\section{RNAi for $\alpha E N a C$ in newborn rat lungs and isolated DLE cells}

We determined if $\mathrm{pSi}-4$ silenced $\alpha \mathrm{ENaC}$ in the newborn rats. After ttip pSi-4-injection, as shown in Fig. $4 \mathrm{~A}, \alpha \mathrm{ENaC}$ mRNA was decreased by 90\%. Western blot results demonstrated a decrease in $\alpha \mathrm{ENaC}$ protein by $\sim 85 \%$ (Fig. $4 \mathrm{~B}$ ). We then investigated if $\alpha E N a C$-silencing affected CFTR expression; as shown in Figs. $4 \mathrm{~A}$ and $4 \mathrm{~B}, \alpha \mathrm{ENaC}$-silencing slightly reduced CFTR mRNA and protein.

We then studied RNAi silencing of $\alpha \mathrm{ENaC}$ in isolated DLE cells after pSi-4 pretreatment. DLE cells (isolated at GD21) were transfected as above with the pDNA 1 day after cell plating. Twenty-four hours after pDNA transfection, i.e., GD22 (birth), $\alpha \mathrm{ENaC}$ and CFTR mRNA and protein were detected by RT-PCR and western blot, respectively. As shown in Fig. 4C, pSi-4-transfection decreased $\alpha \mathrm{ENaC}$ mRNA by $\sim 90 \%$. As seen in Fig. 4D, western blot results demonstrate that, pSi-4-transfection also decreased $\alpha E N a C$ protein by $\sim 90 \%$. Similar to the in vivo situation, CFTR mRNA and protein were less affected by the $\alpha \mathrm{ENaC}$ silencing.

\section{Extravascular lung water}

Extravascular lung water was measured as a functional physiologic endpoint from ttip CFTR in vivo silencing. pSi0 -injected newborn rats displayed the same extravascular lung water as normal, untreated newborn rats. Extravascular lung water in ttip $\alpha \mathrm{ENaC}$ - and CFTR-silenced newborn rat lungs were both significantly increased after siRNAgenerating pDNA injection (Fig. 5A).

\section{Mortality from in vivo CFTR-silencing}

We then studied if ttip pSi-0-, pSi-4, or pSi- $\mathrm{C}_{2}$-injection affected newborn rat mortality. Newborn rats that died within $1 \mathrm{~h}$ after ttip injection were excluded as injectionrelated abnormalities ( $3-4 /$ litter irrespectively of experimental group). When tabulated, newborn rats that died after $>1$ h demonstrated the following mortality: pSi-0: 1 of 32 rats died, pSi-4: 9 of 40 rats died, and $\mathrm{pSi}^{-\mathrm{C}_{2}}$ : 5 of 43 rats died. The data in Fig. $5 \mathrm{~B}$ demonstrate mortality rates of $<3 \%$ in ttip pSi-0-injected newborn rats, $\sim 23 \%$ in ttip pSi-4-injected newborn rats, and $\sim 12 \%$ in ttip $\mathrm{pSi}^{-\mathrm{C}_{2}} \mathrm{2}^{-}$ injected newborn rats.

\section{Localization of RNAi silencing}

To determine in vivo and in vitro transfection ability of pDNA during our conditions, we detected pSi-0 pDNA lung and kidney presence by PCR. As shown in Fig. 6A, there was a single clear band representing $\mathrm{pSi}-0$ in both ttip pSi-0-transfected lung tissue (equal strength in both right and left lungs) and pSi-0-transfected DLE cells. The same band was completely absent from the kidney samples, thus indicating no expression of our siRNA-generating pDNA (pSi-0) in this organ.

We also examined alveolar distribution of siRNA-generating pDNA $24 \mathrm{~h}$ after ttip pDNA injection for CFTR. DLE cells were isolated from $6 \mathrm{pSi}-0$ - and 6 pSi- $\mathrm{C}_{2}$-transfected newborn rats. As can be seen in Fig. 6B, CFTR mRNA, as determined by RT-PCR, was absent from isolated DLE cells after ttip pSi- $\mathrm{C}_{2}$-injection. 


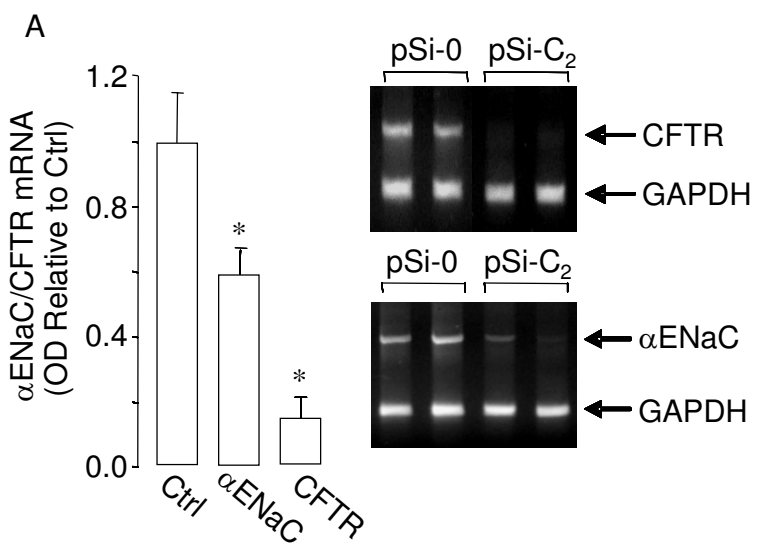

Gene studied

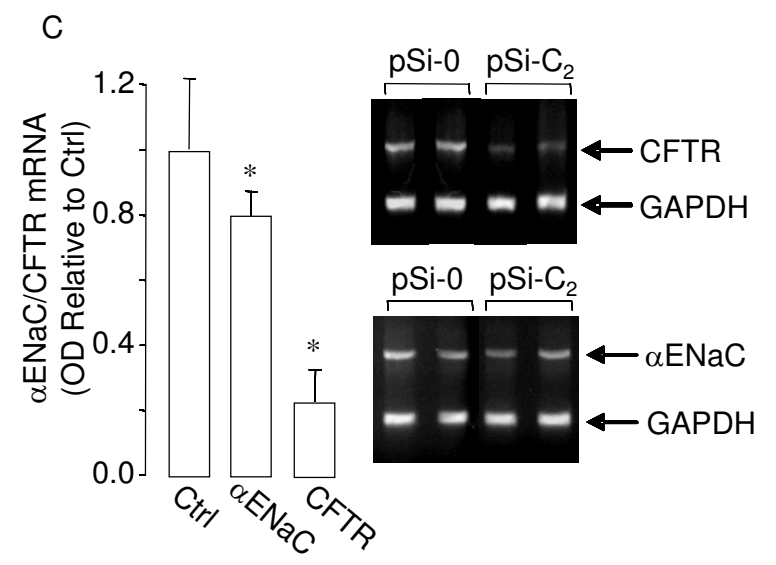

Gene studied

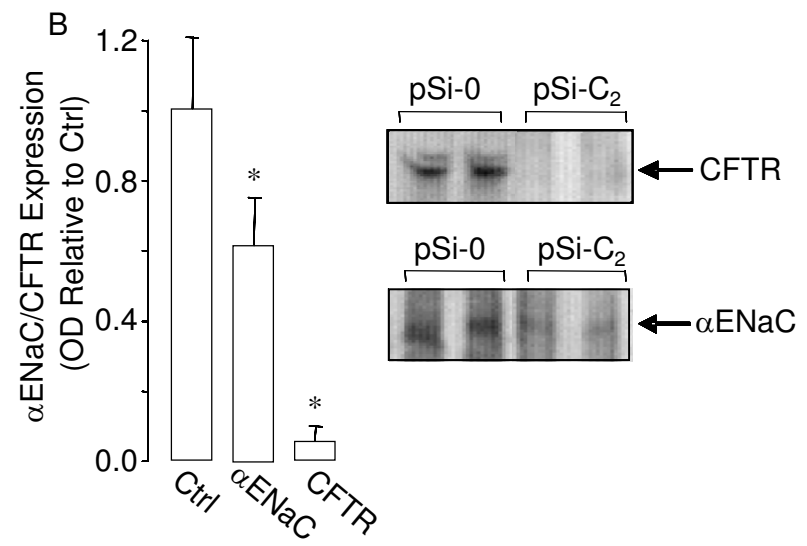

Gene studied

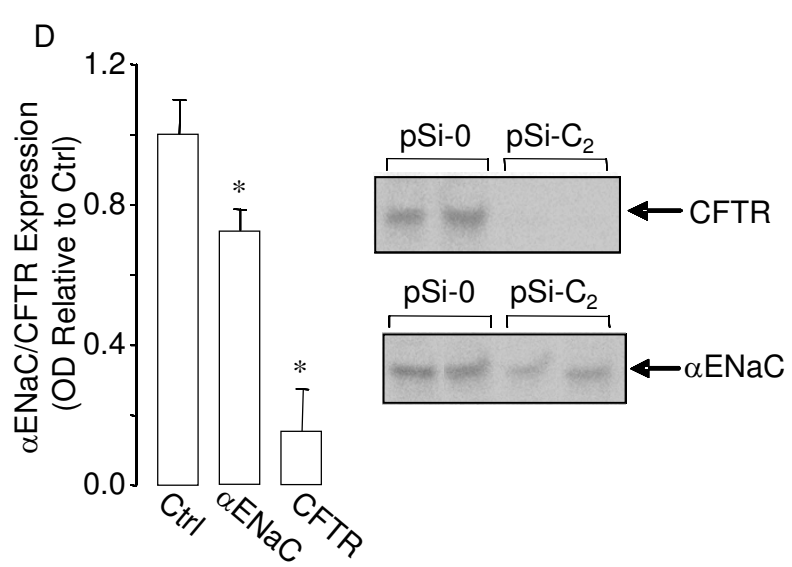

Gene studied

\section{Figure 3}

CFTR and $\alpha E N a C$ mRNA (A) and protein (B) $24 \mathrm{~h}$ after ttip pSi- $\mathrm{C}_{2}$-injection in lung homogenate from newborn rats. Representative RT-PCR gels and western blots are shown for lung homogenate CFTR, $\alpha E N a C$, and GAPDH (internal standard) mRNA and protein. CFTR and $\alpha E N a C$ mRNA (C) and protein (D) $24 \mathrm{~h}$ after transfection of isolated and cultured DLE cells with $p \mathrm{Si}_{-} \mathrm{C}_{2}$. Representative RT-PCR gels and western blots are shown for DLE cell CFTR, $\alpha E N a C$, and GAPDH (internal standard) mRNA and protein.

\section{Organ specificity of RNAi silencing}

To determine organ specificity of the RNAi silencing of CFTR and $\alpha \mathrm{ENaC}$ in vivo in normal untreated newborn rats and in newborn rats $24 \mathrm{~h}$ after ttip pSi-0, pSi-4, and $\mathrm{pSi}-\mathrm{C}_{2}$, we collected kidneys from these rats. In these kidneys, we determined if $\alpha \mathrm{ENaC}$ mRNA varied significantly between our groups. As shown in Fig. 7, there were similar expression of $\alpha \mathrm{ENaC}$ mRNA irrespectively which siRNAgenerating pDNA that was used.

\section{Discussion}

There were four important findings in our studies. First, ttip injection of specific CFTR siRNA-generating pDNA $\left(\mathrm{pSi}-\mathrm{C}_{2}\right)$ increased extravascular lung water and mortality rate of newborn rats. Second, ttip $\mathrm{pSi}^{-} \mathrm{C}_{2}$-injection decreased CFTR mRNA and protein in both in vivo newborn rat lungs and isolated, $\mathrm{pSi}-\mathrm{C}_{2}$-transfected DLE cells. Third, CFTR-silencing by ttip pSi- $\mathrm{C}_{2}$-injection was specific. Fourth, ttip CFTR-silencing also reduced $\alpha \mathrm{ENaC}$ mRNA and protein expression, thus suggesting involvement of CFTR in regulation of $\mathrm{ENaC}$ at the conversion from lung fluid secretion to fluid absorption near term. Fifth, ttip $\alpha \mathrm{ENaC}$ silencing caused a slight reduction in CFTR mRNA and protein expression, further supporting a role for both proteins in the development of lung fluid absorption mechanisms.

The majority of infants make the transition from intrauterine life to postnatal life without complications, but only hours before birth, lungs are filled with an essentially 


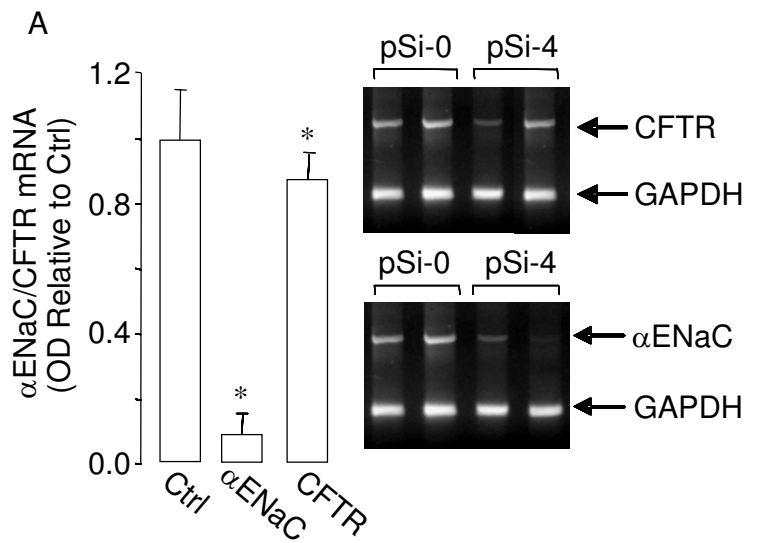

Gene studied

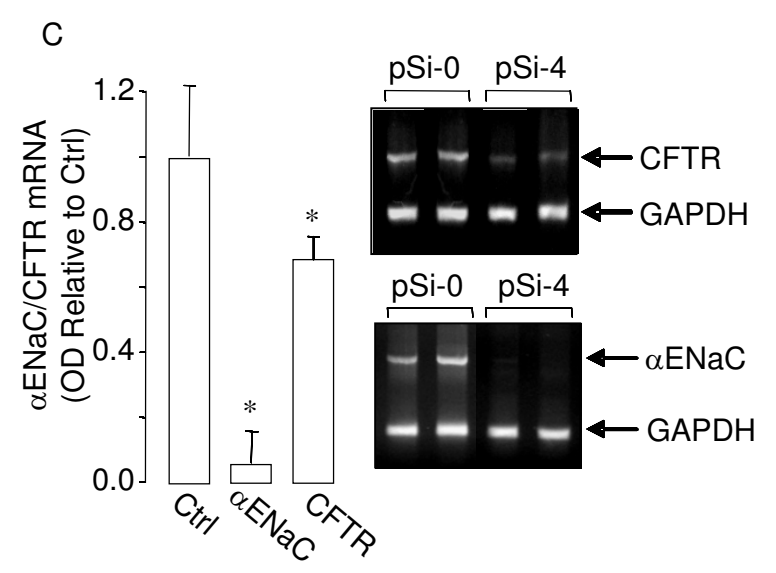

Gene studied

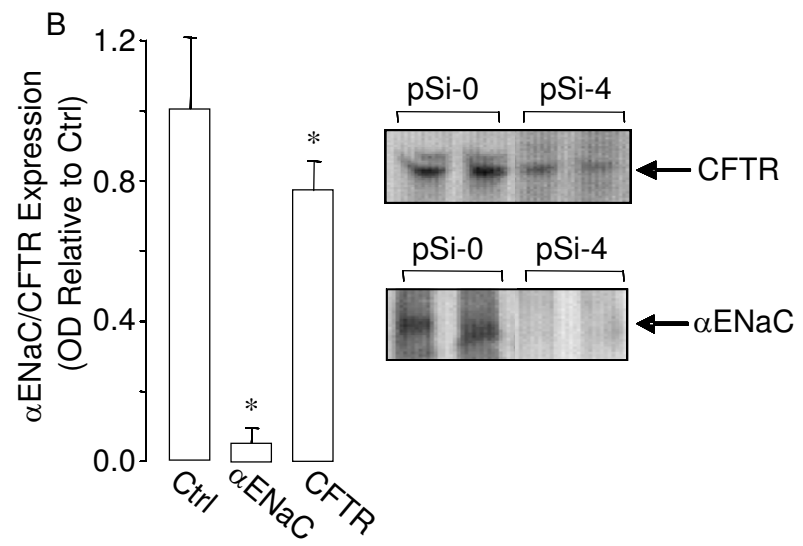

Gene studied

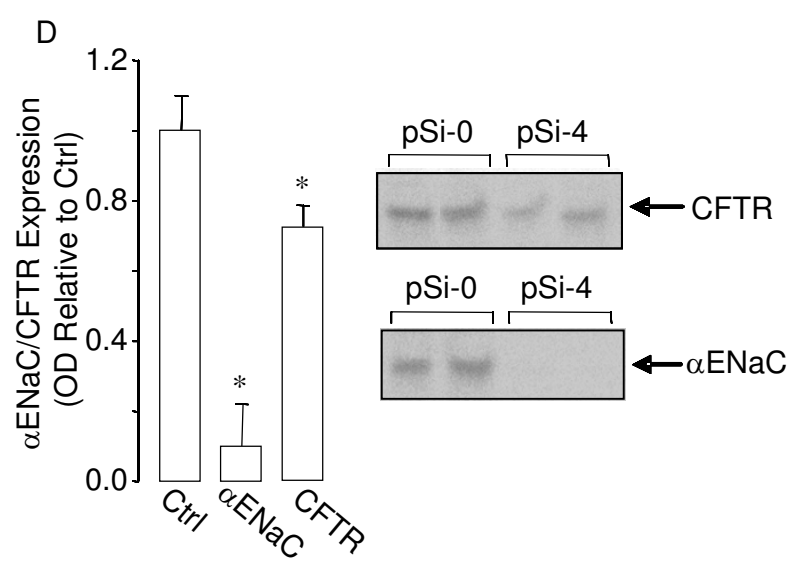

Gene studied

\section{Figure 4}

$\alpha E N a C$ and CFTR mRNA (A) and protein (B) $24 \mathrm{~h}$ after ttip pSi-4-injection in lung homogenate from newborn rats. Representative RT-PCR gels and western blots are shown for lung homogenate $\alpha E N a C, C F T R$, and GAPDH (internal standard) mRNA and protein. $\alpha E N a C$ and CFTR mRNA (C) and protein (D) $24 \mathrm{~h}$ after transfection of isolated and cultured DLE cells with pSi-4. Representative RT-PCR gels and western blots are shown for DLE cell $\alpha E N a C, C F T R$, and GAPDH (internal standard) mRNA and protein.

protein-free isosmolar solution that has been actively secreted by the lung epithelium. The normal rate of lung fluid absorption in newborn rats has been determined earlier [12] and was not apparent before birth, reached a high rate immediately after birth, and decreased to the rate seen in adult rats by $40 \mathrm{~h}$ of newborn life. The molecular mechanism responsible for perinatal lung fluid absorption has been proposed to be $\mathrm{ENaC}$, as mice deficient in $\alpha \mathrm{ENaC}$ expression dies within $40 \mathrm{~h}$ of birth from failure to clear fetal lung fluid [8]. mRNA for $\alpha \mathrm{ENaC}$ is found earliest at GD19, while both $\beta$ and $\gamma$ subunits are expressed at or after birth [26]. This expression patterns agrees well with the observed amiloride-sensitivity and function of fetal rat lungs at birth in the earlier study [12], especially since $\mathrm{ENaC}$ requires all three subunits to become fully functional. Recent studies have demonstrated that failure in lung fluid absorption at birth may be associated with ENaC deficiency [27-29]. In some cases, such as congenital diaphragmatic hernia $(\mathrm{CDH}), \mathrm{ENaC}$ deficiency may have serious impact on lung fluid absorption at birth and drastically affect the ability to oxygenate the newborn [29]. In our current study, silencing CFTR with $\mathrm{pSi}-\mathrm{C}_{2}$ was associated with elevated extravascular lung water and an increased mortality rate, thus strengthening the assumption of CFTR being involved in the transition from fluid-filled fetal lungs to air-filled newborn lungs at birth. ENaC and $\mathrm{Cl}$ transport proteins, such as CFTR, are two important membrane components expressed in the epithelial lining of lung alveoli [30]. An earlier rat study has reported that fetal lung fluid absorp- 
A

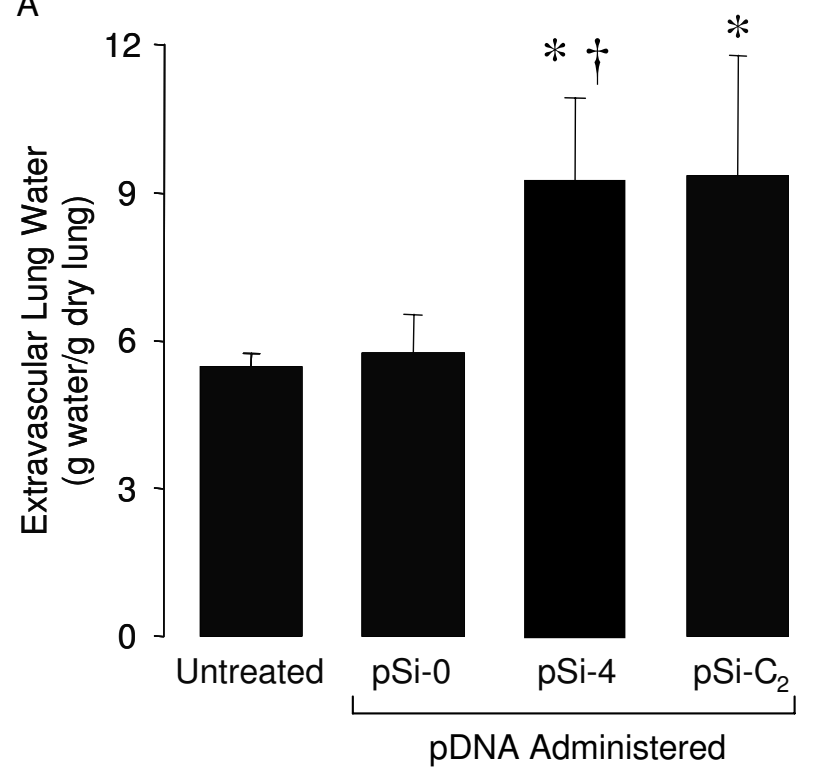

B

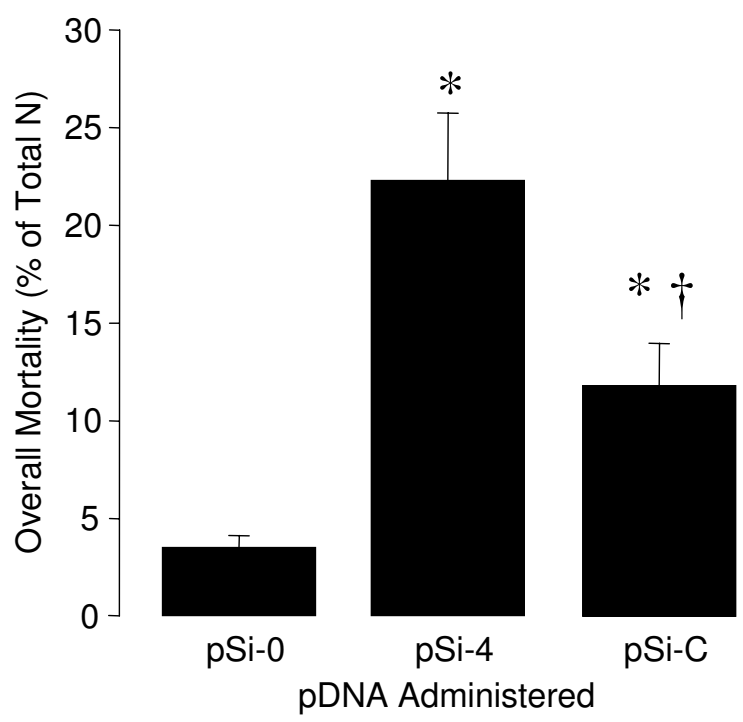

Figure 5

Extravascular lung water $(A)$ in newborn rats $24 \mathrm{~h}$ after ttip pSi-0- and $\mathrm{pSi}-\mathrm{C}_{2}$-injections compared to untreated normal newborn age-matched rats. Mortality (B) in newborn rats $24 \mathrm{~h}$ after ttip pSi-0- and pSi- $\mathrm{C}_{2}$-injections compared to untreated normal newborn age-matched rats.

tion was mediated by $\beta$ AR stimulation [12]. However, the elevated lung fluid absorption rate in GD22 rat fetuses was only minimally amiloride-sensitive and increased in amiloride-sensitivity during the first $40 \mathrm{~h}$ of postnatal life [12]. In the current study, we investigated how CFTR transcription changed during early postnatal development. CFTR maintained a relatively high expression at birth and reached adult levels at the $2^{\text {nd }}$ postnatal day.

In our earlier study [9], $\alpha \mathrm{ENaC}$ gene silencing in adult rat lungs was achieved by siRNA generating pDNA, where the pDNA was delivered conjugated with liposomal complexes by intratracheal instillation. This method was originally developed by Folkesson and colleagues [31] and took advantage of the anatomical characteristics of the lung. To deliver pDNA in the original study [9] we utilized a modification of the discoveries by Sawa and colleagues [32], where they demonstrated that intraluminal water instillation into the lung increased transfection efficiency. However, this instillation technique is not suitable for newborn rats due to their small size. It has been demonstrated that DNA can be directly delivered to skeletal muscle by intramuscular injection of 'naked' pDNA [33]. The gene transfer was, however, restricted to muscle cells adjacent to the route of injection [33]. A more recent study by Bhargava and colleagues [34] demonstrated that site-specific transient gene knockdown can be achieved by local double-strand RNA hypothalamic injection. In our current study, we modified the siRNA-delivery methods by developing a repeatable ttip injection technique using a pDNA $(\mu \mathrm{g})$ :liposome $(\mu \mathrm{l})$ ratio $1: 1$ with a pDNA concentration $4 \mu \mathrm{g} / \mathrm{g}$ body wt in a final volume of $40 \mu \mathrm{l} / \mathrm{g}$ body wt and with a low osmolality of $100 \mathrm{mOsm}$. Our results showed a reproducible specific siRNA-mediated $\alpha E N a C$ and CFTR-silencing, about $~ 80-85 \%$ for both mRNA and protein, in newborn rat lungs by this method. In addition, our method was organ specific and did not affect $\mathrm{ENaC}$ expression in the kidney, another organ where $\mathrm{ENaC}$ is highly expressed, nor did the pDNA itself reach the kidneys. We also demonstrated that our siRNA-generating pDNAs did not reach the kidney after the ttip injections. In our recent publication [23] using this technique, we demonstrated the involvement of Nedd4-2 in ENaC membrane regulation and the importance for newborn lung conversion for fluid secretion to absorption in the rat.

An additional limitation of our data might be that the delivery of the siRNA-generating pDNAs invoked an interferon and/or cytokine response. Since both $\mathrm{ENaC}$ and CFTR can be affected by cytokines and interferons [35,36], this could potentially explain the downregulation of $\mathrm{ENaC}$ when the CFTR was silenced. However, for multiple reasons we do not believe this to be the case. First, since 
A

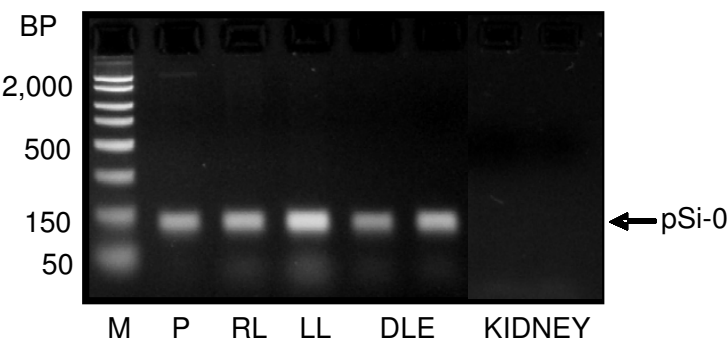

B

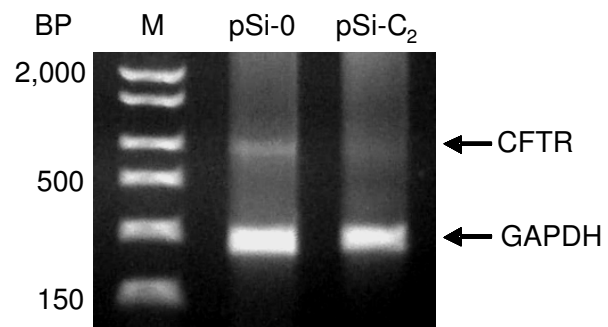

Figure 6

Localization of pSi-0 pDNA $24 \mathrm{~h}$ following ttip pSi-0injection in newborn rat lungs, in isolated DLE cells, and in the kidney $(A)$ and identifying of the specific CFTR-silencing to the DLE cells $24 \mathrm{~h}$ after in vivo ttip administration (B). A representative RT-PCR gel is shown for lung CFTR and GAPDH (internal standard) mRNA. (BP: base pairs; M: marker; P: purified plasmid; RL: right lung; LL: left lung) the interferon response is a response to the introduction of a siRNA to the cells, pSi-0 should also have caused a downregulation of ENaC and CFTR. This never occurred in these or our earlier studies $[9,23]$. Second, albeit more speculative, earlier studies suggest that introduction of pure siRNA directly to the cells were more likely to cause an interferon response than the introduction of siRNAgenerating pDNA or phage-mediated transfection [3739]. Third, all ENaC subunits, $\alpha-, \beta-$, and $\gamma$, would likely have been downregulated when $\alpha \mathrm{ENaC}$ was silenced had there been an interferon response of significance. Fourth, in our earlier study [23], when Nedd4-2 was silenced, the expression of $\mathrm{ENaC}$ increased. Thus all this evidence argues against that a major interferon and/or cytokine response would be occurring in these studies.

As a functional endpoint, we evaluated changes in extravascular lung water and mortality following ttip pSi$\mathrm{C}_{2}$. Interestingly, extravascular lung water was increased after ttip $\mathrm{pSi}-\mathrm{C}_{2}$-injection. Moreover, $\mathrm{pSi}-\mathrm{C}_{2}$-injection resulted in an increased mortality. These results indicate that CFTR is involved in the transition from lung fluid secretion to fluid absorption at birth. $\alpha \mathrm{ENaC}$ silencing resulted in a similar increase in extravascular lung water, with an even higher increase in mortality. The mortality rate, however, was not the same as $\alpha \mathrm{ENaC}$ gene knockout mice studies [8], possibly because the siRNA-generating pDNA was administered after birth, in contrast to a gestational knockout. It may also be associated with the fact that ttip pSi- 4 and pSi- $\mathrm{C}_{2}$-injection only silenced $\alpha \mathrm{ENaC}$ and CFTR in the lung and thus we avoided unspecific systemic side-effects from $\alpha \mathrm{ENaC}$ and CFTR knockdown in other organs, i.e., the GI tract. A third possibility is that siRNA-mediated $\alpha \mathrm{ENaC}$ and/or CFTR knockdown was

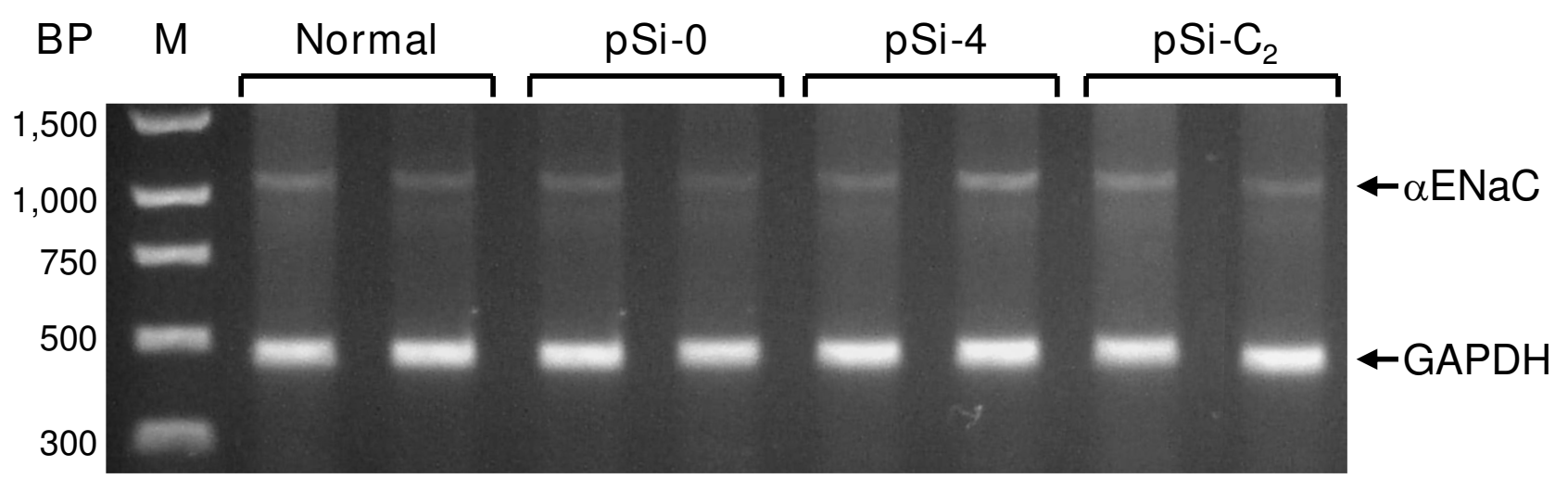

Figure 7

$\alpha E N a C$ mRNA in normal untreated and $24 \mathrm{~h}$ after ttip pSi-0-, pSi-4-, and pSi- $\mathrm{C}_{2}$-injection in kidney homogenate from newborn rats. A representative RT-PCR gel is shown for kidney homogenate $\alpha E N a C$ mRNA. (BP: base pairs; M: marker) 
incomplete and left residual $\alpha \mathrm{ENaC}$ and CFTR expression in the lung. When a rescue model with $\mathrm{CMV}$ promoterdriven rat $\alpha \mathrm{ENaC}$ expression in the $-/-\alpha \mathrm{ENaC}$ mouse lung was utilized, a very low $\alpha \mathrm{ENaC}$ expression was encountered and this was apparently sufficient to rescue $~ 50 \%$ of the mouse pups at birth [40]. The mortality may also be attributable to that CFTR knockdown reduced $\alpha \mathrm{ENaC}$ mRNA and protein by $\sim 20-40 \%$, since $\mathrm{ENaC}$ deficiency is lethal.

Factors implied to regulate lung fluid absorption and $\mathrm{ENaC}$ expression in the newborn include $\beta A \mathrm{~A}$ agonists, glucocorticoid hormones, thyroid hormones, and oxygen concentrations [12,41-44]. Key $\mathrm{Na}$ transport proteins involved are the basolateral $\mathrm{Na}$,K-ATPase, that provides the driving force, and $\mathrm{ENaC}$ provides an apical pathway for Na entry into the epithelial cells [30]. Evidence has been brought forward suggesting that $\mathrm{ENaC}$ activation requires CFTR $\mathrm{Cl}$ channel function $[45,46]$. A number of hypotheses have been presented how CFTR control ENaC activity [47]. Research supports the hypotheses that there are ENaC-CFTR interactions related to electrical coupling of ion fluxes in epithelial cells [48]. Regulation of apical $\mathrm{Na}$ channels (ENaC and other Na channels) has been attributed to changes in cytosolic $\mathrm{Ca}, \mathrm{Cl}$ concentration, and $\mathrm{pH}$ [49]. Our results indicate that ENaC and CFTR expression levels appear to correlate with each other at this critical stage of lung development. However, if one is affected by gene silencing (artificially or naturally by mutation), a functional deficiency of this channel may also affect the function/expression other channels. Potentially this may be explained as that ion flow through the channel, either partially or wholly, depends on the electrochemical potential. Thus, when two channels are active in the same membrane they would benefit from being able to influence each other's expression/function. The "electrical coupling" of $\mathrm{Cl}$ and $\mathrm{Na}$ conductances require that these two conductances are expressed in parallel at the apical epithelial cell membrane with a significant impact on each other. Our results also suggest an "expression coupling" that support and may provide some molecular background of the "electrical coupling" between $\mathrm{ENaC}$ and CFTR.

Was this "expression coupling" between ENaC and CFTR an "animal-only phenomenon" or could it be reproduced in simpler system such as cell systems? To answer this question we isolated and cultured DLE cells and transfected them in vitro with pSi- 4 or $\mathrm{pSi}^{-\mathrm{C}_{2}}$ pDNA. DLE cell isolation was done on GD21 fetuses, transfection was done 1 day later, and $\alpha \mathrm{ENaC}$ and CFTR expression measured after another day of incubation. We decided on this protocol since it mimicked the time points when the newborn rats were transfected in vivo. Transfection of DLE cells with pSi-C $\mathrm{C}_{2}$ resulted in a knockdown of CFTR, as observed in the newborn rat in vivo. Moreover, when $\mathrm{pSi}-\mathrm{C}_{2}$-transfected cells were assayed for $\alpha \mathrm{ENaC}$ expression, we found that $\alpha \mathrm{ENaC}$ mRNA and protein were all decreased, also as observed in the newborn rats. Reversely, when the DLE cells were transfected with $\mathrm{pSi}-4, \alpha \mathrm{ENaC}$ expression was decreased very significantly, while CFTR expression was much less affected. Thus, the "ENaC-CFTR expression coupling" was indeed present in the isolated DLE cells.

In conclusion, our data demonstrate by using selective siRNA inhibition of CFTR expression that both CFTR and $\mathrm{ENaC}$ are involved in the transition from lung fluid secretion to lung fluid absorption at birth. Our data also suggest that $\mathrm{ENaC}$, being the principal agent stimulating lung fluid absorption at birth, may possibly depend on CFTR expression/function. Both CFTR and $\mathrm{ENaC}$ seem to be interdependent to each other in order to generate the driving force for perinatal lung fluid absorption.

\section{Competing interests}

The authors declare that they have no competing interests.

\section{Authors' contributions}

TL and SK carried out the experimental studies and drafted the manuscript. HGF designed the experimental setup, supervised the work, and provided intellectual input for the manuscript preparation. All authors have read the final version and approved it.

\section{Acknowledgements}

The authors wish to express their thanks to our Sr. Research Associate Cheryl M. Hodnichak for her hard and dedicated work on this project. We also want to thank Dr. Walter I. Horne, DVM for his initial suggestions for the development of the pDNA administration technique.

\section{Grant}

The current study was supported by Research Grant \#6-FY03-64 from March of Dimes Birth Defects Foundation and Ohio Board of Regents Research Incentive Grant 2008.

\section{References}

I. Kochanek KD, Murphy SL, Anderson RN, Scott C: Deaths: final data for 2002. Natl Vital Stat Rep 2004, 53:I-I I5.

2. Bland RD, Nielson DW: Developmental changes in lung epithelial ion transport and liquid movement. Annu Rev Physiol 1992, 54:373-394.

3. Matthay MA, Folkesson HG, Verkman AS: Salt and water transport across alveolar and distal airway epithelium in the adult lung. Am J Physiol 1996, 270(4 Pt I):L487-L503.

4. Folkesson HG, Norlin A, Baines DL: Salt and water transport across the alveolar epithelium in the developing lung: Correlations between function and recent molecular biology advances (Review). Int J Mol Med 1998, 2:5 I5-53I.

5. Matalon S, Lazrak A, Jain L, Eaton DC: Biophysical properties of sodium channels in lung alveolar epithelial cells. J Appl Physiol 2002, 93: 1852-1859.

6. Matthay MA, Folkesson HG, Clerici C: Lung epithelial fluid transport and the resolution of pulmonary edema. Physiol Rev 2002, 82:569-600.

7. Olver RE, Walters DV, Wilson SM: Developmental regulation of lung liquid transport. Annu Rev Physiol 2004, 66:77-10I. 
8. Hummler E, Barker P, Gatzy J, Beermann F, Verdumo C, Schmidt A, Boucher R, Rossier BC: Early death due to defective neonatal lung liquid clearance in $\alpha E N a C$-deficient mice. Nat Genet 1996, I 2:325-328.

9. $\mathrm{Li}$ T, Folkesson HG: RNA interference for $\alpha$-ENaC inhibits rat lung fluid absorption in vivo. Am J Physiol Lung Cell Mol Physiol 2006, 290:L649-L660.

10. Ingbar DH, Burns Weeks C, Gilmore-Hebert M, Jacobsen E, Duvick S, Dowin R, Savik SK, Jamieson JD: Developmental regulation of $\mathrm{Na}, \mathrm{K}-\mathrm{ATPase}$ in rat lung. Am J Physiol 1996, 270:L619-L629.

II. Sznajder JI, Factor P, Ingbar DH: Lung edema clearance: role of $\mathrm{Na}^{+}-\mathrm{K}^{+}$-ATPase. J Appl Physiol 2002, 93:1860-1866.

12. Folkesson HG, Matthay MA, Chapin CJ, Porta NFM, Kitterman JA: Pre- and postnatal lung development, maturation, and plasticity: Distal air space epithelial fluid clearance in near-term rat fetuses is fast and requires endogenous catecholamines. Am J Physiol Lung Cell Mol Physiol 2002, 282:L508-L5I5.

13. Jiang $X$, Ingbar DH, O'Grady SM: Adrenergic stimulation of $\mathrm{Na}^{+}$ transport across alveolar epithelial cells involves activation of apical $\mathrm{Cl}^{-}$channels. Am J Physiol 1998, 275(6 Pt I): $\mathrm{Cl} 610-\mathrm{Cl} 620$

14. Fang X, Fukuda N, Barbry P, Sartori C, Verkman AS, Matthay MA: Novel role for CFTR in fluid absorption from the distal airspaces of the lung. J Gen Physiol 2002, I I9:199-208.

15. Borok Z, Liebler JM, Lubman RL, Foster MJ, Zhou B, Li X, Zabski SM, Kim K-J, Crandall ED: Alveolar epithelial ion and fluid transport: $\mathrm{Na}$ transport proteins are expressed by rat alveolar epithelial type I cells. Am J Physiol Lung Cell Mol Physiol 2002, 282:L599-L608.

16. Johnson MD, Widdicombe JH, Allen L, Barbry P, Dobbs LG: Alveolar epithelial type I cells contain transport proteins and transport sodium, supporting an active role for type I cells in regulation of lung liquid homeostasis. Proc Natl Acad Sci USA 2002, 99:1966-1971.

17. Ballard ST, Schepens SM, Falcone JC, Meininger GA, Taylor AE: Regional bioelectric properties of porcine airway epithelium. J Appl Physiol 1992, 73:2021-2027.

18. Al-Bazzaz F): Regulation of $\mathbf{N a}$ and $\mathrm{Cl}$ transport in sheep distal airways. Am J Physiol 1994, 267(2 Pt I):L193-LI98.

19. Johnson MD, Bao HF, Helms MN, Chen XJ, Tigue Z, Jain L, Dobbs LG, Eaton DC: Functional ion channels in pulmonary alveolar type I cells support a role for type I cells in lung ion transport. Proc Natl Acad Sci USA 2006, 103:4964-4969.

20. Barker PM, Nguyen MS, Gatzy JT, Grubb B, Norman H, Hummler E, Rossier B, Boucher RC, Koller B: Role of $\gamma$ ENaC subunit in lung liquid clearance and electrolyte balance in newborn mice. Insights into perinatal adaptation and pseudohypoaldosteronism. J Clin Invest 1998, 102:1634-1640.

21. Snouwaert JN, Brigman KK, Latour AM, Malouf NN, Boucher RC, Smithies $\mathrm{O}$, Koller $\mathrm{BH}$ : An animal model for cystic fibrosis made by gene targeting. Science 1992, 257:1083-1088.

22. Sambrook J, Fritsch EF, Maniatis T: Molecular cloning: A laboratory manual. 3rd edition. Plainview, N.Y., USA: Cold Spring Harbor Laboratory Press, Inc; 200I.

23. Li T, Koshy S, Folkesson HG: Involvement of $\alpha E N a C$ and Nedd4$\mathbf{2}$ in the conversion from lung fluid secretion to fluid absorption at birth in the rat as assayed by RNA interference analysis. Am J Physiol Lung Cell Mol Physiol 2007, 293:L 1069-LI078.

24. Jassal D, Han RN, Caniggia I, Post M, Tanswell AK: Growth of distal fetal rat lung epithelial cells in a defined serum-free medium. In Vitro Cell Dev Biol Anim I991, 27A:625-632.

25. Selinger SL, Bland RD, Demling RH, Staub NC: Distribution of volumes of ${ }^{131} \mathrm{I}$-albumin, ${ }^{14} \mathrm{C}$-sucrose and ${ }^{36} \mathrm{Cl}$ in sheep. J Appl Physiol 1975, 39:773-779.

26. Tchepichev S, Ueda J, Canessa C, Rossier BC, O'Brodovich H: Lung epithelial $\mathrm{Na}$ channel subunits are differentially regulated during development and by steroids. Am J Physiol 1995, 269(3 Pt I):C805-C812

27. Barker PM, Gowen CW, Lawson EE, Knowles MR: Decreased sodium ion absorption across nasal epithelium of very premature infants with respiratory distress syndrome. J Pediatr 1997, 130:373-377.

28. O'Brodovich $\mathrm{H}$ : Deficient $\mathrm{Na}^{+}$channel expression in newborn respiratory distress syndrome. Pediatr Pulmonol Suppl 2004, 26:141-142
29. Folkesson HG, Chapin C, Beard LL, Ertsey R, Matthay MA, Kitterman JA: Congenital diaphragmatic hernia prevents clearance of distal airspace fluid in late-gestation rat fetuses. Am J Physiol Lung Cell Mol Physiol 2006, 290:L478-L484.

30. Garty H, Palmer LG: Epithelial sodium channels: Function, structure, and regulation. Physiol Rev 1997, 77:359-396.

31. Folkesson HG, Weström BR, Karlsson BW: Permeability of the respiratory tract to different-sized macromolecules after intratracheal instillation in young and adult rats. Acta Physiol Scand 1990, 139:347-354.

32. Sawa T, Miyazaki H, Pittet J-F, Widdicombe JH, Gropper MA, Hashimoto S, Conrad DJ, Folkesson HG, Debs R, Forsayeth JR, Fox B, Wiener-Kronish JP: Intraluminal water increases expression of plasmid DNA in rat lung. Hum Gene Ther 1996, 7:933-94I.

33. Wolff JA, Malone RW, Williams P, Chong W, Acsadi G, Jani A, Felgner PL: Direct gene transfer into mouse muscle in vivo. Science 1990, 247: 1465- I 468.

34. Bhargava A, Dallman MF, Pearce D, Choi S: Long double-stranded RNA-mediated RNA interference as a tool to achieve sitespecific silencing of hypothalamic neuropeptides. Brain Res Brain Res Protoc 2004, I 3: I I 5- I 25.

35. Roux J, Kawakatsu H, Gartland B, Pespeni M, Sheppard D, Matthay MA, Canessa CM, Pittet JF: Interleukin- I $\beta$ decreases expression of the epithelial sodium channel $\alpha$-subunit in alveolar epithelial cells via a p38 MAPK-dependent signaling pathway. J Biol Chem 2005, 280: I8579-18589.

36. Berger M: Inflammatory mediators in cystic fibrosis lung disease. Allergy Asthma Proc 2002, 23:19-25.

37. Li S, Wu SP, Whitmore M, Loeffert EJ, Wang L, Watkins SC, Pitt BR, Huang $L$ : Effect of immune response on gene transfer to the lung via systemic administration of cationic lipidic vectors. Am J Physiol 1999, 276(5 Pt I):L796-L804.

38. Ma Z, Li J, He F, Wilson A, Pitt B, Li S: Cationic lipids enhance siRNA-mediated interferon response in mice. Biochem Biophys Res Comm 2005, 330:755-759.

39. Gondai T, Yamaguchi K, Miyano-Kurosaki N, Habu Y, Takaku H: Short-hairpin RNAs synthesized by T7 phage polymerase do not induce interferon. Nucleic Acids Res 2008, 36: el 8.

40. Hummler E, Barker P, Talbot C, Wang Q, Verdumo C, Grubb B, Gatzy J, Burnier M, Horisberger J-D, Beermann F, Boucher R, Rossier $B C$ : A mouse model for the renal salt-wasting syndrome pseudohypoaldosteronism. Proc Natl Acad Sci USA 1997, 94:11710-11715.

4I. Barker PM, Markiewicz M, Parker KA, Walters DV, Strang LB: Synergistic action of triiodothyronine and hydrocortisone on epinephrine-induced reabsorption of fetal lung liquid. Pediatr Res 1990, 27:588-59|.

42. Finley N, Norlin A, Baines DL, Folkesson HG: Alveolar epithelial fluid clearance is mediated by endogenous catecholamines at birth in guinea pigs. J Clin Invest 1998, 101:972-98I.

43. Baines DL, Folkesson HG, Norlin A, Bingle CD, Yuan H, Olver RE: The influence of mode of delivery, hormonal status and postnatal $\mathrm{O}_{2}$ environment on epithelial sodium channel (ENaC) expression in perinatal guinea-pig lung. J Physiol 2000, 522:147-157.

44. Barker PM, Olver RE: Lung edema clearance: 20 years of progress. Invited review: Clearance of lung liquid during the perinatal period. J Appl Physiol 2002, 93:1542-1548.

45. Stutts MJ, Canessa CM, Olsen JC, Hamrick M, Cohn JA, Rossier BC Boucher RC: CFTR as a CAMP-dependent regulator of sodium channels. Science 1995, 269:847-850

46. Reddy MM, Light MJ, Quinton PM: Activation of the epithelial $\mathrm{Na}^{+}$channel (ENaC) requires CFTR Cl- channel function. Nature 1999, 402:301-304.

47. Kunzelmann K: The cystic fibrosis transmembrane conductance regulator and its function in epithelial transport. Rev Physiol Biochem Pharmacol 1999, I37: I-70.

48. Horisberger JD: ENaC-CFTR interactions: the role of electrical coupling of ion fluxes explored in an epithelial cell model. Pflugers Arch 2003, 445(4):522-528.

49. Marunaka $Y$, Niisato N, O'Brodovich H, Eaton DC: Regulation of an amiloride-sensitive $\mathrm{Na}^{+}$-permeable channel by a $\beta_{2}$-adrenergic agonist, cytosolic $\mathrm{Ca}^{2+}$ and $\mathrm{Cl}$ - in fetal rat alveolar epithelium. J Physiol 1999, 5 15:669-683. 